zipierten und legitimierten Demokratiebegriffs - Fraenkels Mitmigrant in den USA, Ernst Bloch, nennt die Demokratie den ersten humanen Wohnort der Menschheitsgeschichte 47 - nur eine inhaltlich stark entleerte Sichtweise übrig, die von normativen Fragestellungen, die durch die Verfassung vorgegeben sind, getrennt ist. In einem jüngeren Aufsatz in der »Politischen Vierteljahresschrift « schreibt Dieter Fuchs: »Die Frage, wie präskriptive Merkmale einer idealen Demokratie durch deskriptive Indikatoren operationalisiert werden können, ist bislang völlig ungeklärt. «48 Diese These eines notwendigen Dualismus von empirischer Analyse und kritischer Urteilsbildung zeugt von einer gegenstandsfernen und ahistorischen Begriffsbildung, mit deren Kategorien große, auf die Totalität eines politischen Systems bezogene Arbeiten - wie Eugen Kogons »SSStaat «, Rudolf Bahros »Kritik des real existierenden Sozialismus « oder Norbert Freis »Vergangenheitspolitik«49 - nicht hätten geschrieben werden können.

Fraenkel legte großen Wert »auf die Verknüpfung empirischer und normativer Forschungsmethoden«. Wenn man aber, wie in dem zitierten Aufsatz, deskriptive und normative Methoden gegeneinander stellt und ihre Verbindung in ein gewissermaßen nicht zu lösendes Rätsel verwandelt, setzt man sich diesem durch Fraenkels gesamtes Werk beglaubigtem Urteil aus: »Da Zentralbegriffe der Wissenschaft von der Politik ... an einem Wertsystem ausgerichtet sind, können sie mit den Methoden einer empirisch-deskriptiven Wissenschaft nicht einmal im Ansatz begriffen werden. «50

\title{
Duncan Kennedy A Left Phenomenological Critique of the Hart/Kelsen Theory of Legal Interpretation
}

Der Text greift zunächst die vorwiegend von der linken Rechtskritik vorgebrachten Einwände gegen den Rechtspositivismus von H.L.A. Hart und Hans Kelsen auf und versucht, diese phänomenologisch zu präzisieren. Ausgangspunkt ist die Frage nach der (Un-)Bestimmtheit bzw. Bestimmung von Normen. Im Unterschied zu Hart und Kelsen geht die phänomenologische Kritik davon aus, dass Rechtsanwendung nicht nur aus Kognition und Ermessen besteht, sondern zunächst die Konstruktion der Normanwendungssituation voraussetzt. Sie rückt damit »Begriffskerne«, »Rahmen«, Lücken und Konflikte ins Zentrum der Rechtsarbeit. Diese ist sowohl dynamisch als auch strategisch, geleitet von Vorurteilen wie von Ideologien und politischen Projekten, und entfernt sich damit vom Bild der positivistischen Rechtsanwendung. Im zweiten Teil des Textes verteidigt der Autor die im Rahmen der Critical Legal Studies (CLS) entwickelte Unbestimmtheitskritik gegen »Misreadings « durch die Vertreter des Mainstream, insbesondere gegen den Vorwurf des Rechtsnihilismus. CLS geht, im Anschluss an die Hart/Kelsen-Kritik, davon aus, dass die (Un-)Bestimmt-

47 Ernst Bloch, Das Prinzip Hoffnung, Frankfurt am Main 1959, S. I608.

48 Dieter Fuchs, Konzept und Messung von Demokratie, Politische Vierteljahresschrift H. I /2002, S. i०4 f.

49 Kogon (Fn. 38); Rudolf Bahro, Die Alternative. Zur Kritik des real existierenden Sozialismus, Köln I977; Frei (Fn. 4I).

50 Ernst Fraenkel, Die Wissenschaft von der Demokratie und die Gesellschaft (1963), in: Fraenkel, Gesammelte Schriften (Fn. 2), S. 337. 
heit keine Funktion der Worte gültiger Normen und des Inhalts anderer Rechtsquellen ist (semantische Unbestimmtheit), sondern aus der Interaktion zwischen den Ressourcen und Strategien der Rechtsanwender resultiert (strukturelle Unbestimmtheit). Daraus folgt, dass richtige richterliche Entscheidungen zwar nicht gänzlich unmöglich, aber deutlich schwieriger zu finden sind, als von Mainstream-Autoren angenommen wird.

Die Red.

\section{Hart and Kelsen on Legal Interpretation}

This part concerns the following set of ideas common to Hart's and Kelsen's canonical brief writings on legal interpretation. ${ }^{\mathrm{I}}$ Within a »core, « or at the boundary of the »frame« established by a norm, interpretation is »determinate.« In the "penumbra « or »within the frame « set up by the norm, interpretation is another word for »discretion « or »legislation, « and the meaning that the interpreter will give the norm is not determinate.

For Kelsen and Hart, determinacy of a given norm, seen as a unit, is a matter of degree. For Kelsen, constitutional norms defining the proper exercise of legislative power are relatively indeterminate as to what statutes the legislature should adopt, while statutes are relatively more determinate of the content of judicial decisions purporting to apply them. Likewise, for Hart norms can have larger or smaller penumbras.

Both authors use the word determinate in a confusing way. Sometimes determinate means that we can predict with great certainty what the interpreter will do with the problem at hand. But at the same time, it seems to mean that the operation is »cognitive « in the sense that we understand it to be a judgment about a meaning, understood to be something that is independent of the observer, and with respect to which we believe there is a »truth of the matter «, even if interpreters are likely to disagree about what that truth is. I don't think either of them thought this made a lot of difference, but in what follows I will argue that they were wrong.

For both authors, the determinate operation is not problematized. They characterize it as though the cognition of a correct meaning for the core or frame, or the highly predictable choice of interpretation, were automatic and effortless, supposing good faith. For Hart it is the application of a norm to a case whose (legally established facts) bring it within the core of the norm's meaning. For Kelsen, it is the refusal of an interpretation of the norm that would lie outside the frame delimiting the possible meanings of the norm.

In other words, when the judge applies the rule about vehicles in the park to an automobile being driven through the park, the rule as applied is determinate. When the Kelsenian interpreter claims that there is a gap, it is, says Kelsen, usually the case that »in fact « there is merely a tension between a validly established norm of no liability for the defendant, as it applies to the case in hand, and the politics of the interpreter. Here a determinate norm is being given a wrong interpretation, one outside of the frame defining the possible meanings of the norm. One of the most striking and peculiar aspects of the Hart/Kelsen theory of interpretation is that it seems to be a version of »exegese, « or »literalism. «In other words, Hart/Kelsen are explaining how interpretation works when there is a 
single norm that either does or does not make the defendant liable to the plaintiff given the facts of the case. Surprisingly enough, neither addresses one way or another the interpretive practice that seem most characteristic of their own period of European legal history, namely interpretation using the method of »constructions « or »coherence« or »conceptual jurisprudence« (Begriffsjurisprudenz). We can distinguish this method from literalism as follows.

Conceptual jurisprudence accepts that there will be situations in which there is more than one valid norm (section of the code or binding precedent) that is arguably applicable to the facts, and that different norms will give different outcomes for the case. Conceptual jurists (and their critics, e.g., Geny in Methode) have also have tended to believe that there are situations that are "new « in the specific sense that no valid legal norm was specifically intended to determine them one way or another. The method requires the judge to deal both with conflicts and with gaps as follows: he is to presuppose the coherence of »the system « as a whole, and then to ask which of the conflicting norms, or what new norm, made applicable to the case, »fits « best with closely related norms, and if this is not clear, with the more abstract norms, explicit or implicit in »the system, «from which the particular norms are understood to derive (Savigny).

From the point of view of Hart/Kelsen, the operation of "construction « through which a conceptual jurist deals with the conflict or gap is discretionary and »legislative." But what counts for us is that before the construction begins, there has already been a judgment, not theorized, that the gap or conflict »exists. « This, in practice, is treated as a cognition of the interpreter, but unlike the conceptual jurist's highly self-conscious operation of construction, in which induction and deduction supposedly guarantee the objective validity of the choice of norm, the initial framing of the situation as conflict or gap is not theorized.

Along with literalism and conceptual jurisprudence, the third method of interpretation of legal norms that is current in the Western legal domain is policy analysis, or the method of balancing or proportionality. Here, the interpreter understands himself to have a choice between norms or between formulations of the norm, a choice that is resolved by appeal to the conflicting considerations that he understands to underlie the norm system as a whole. There are many variants of the method of policy analysis. What is balanced might be conflicting rights, principles, or instrumental goals supposedly of common interest, along with interests in administrability (vs. equitable flexibility), and system maintenance interests, such as that in the preservation of the separation of powers. Or all of the above.

For Hart/Kelsen it is important that policy analysis uses considerations that are discretionary or legislative. But for our purposes, what counts is not how policy analysis is done, but how the situation is framed as one in which it is possible, or required. In other words, before the policy analysis begins, whatever its content, the interpreter explicitly or implicitly frames the situation as one in which there is a conflict or a gap that exempts him from the elementary duty to apply a clear norm when the facts clearly fit within its definitions. This initial framing is not theorized by the authors who developed policy analysis.

This paper asks how we can understand the framing of a problem of interpretation, that is the process by which the interpreter constitutes the situation in either of two ways: either as one in which all that is required is application of a norm, or as one in which, because we are in the penumbra or within the Kelsenian frame, or there is a conflict or a gap, something more than mere application of a norm is required (the »something more« being choice among eligible interpretations based on leg- 
islative discretion, coherence analysis, or policy analysis). The italicized words are meant to indicate the points of departure from positivist and post-positivist theories of interpretation. There are two aspects to our inquiry. The first is as to the process by which the interpreter decides what norm or norms to interpret in a given case. The second is as to the process by which the interpreter decides that the facts of the case locate it in the core or the penumbra, outside or within the Kelsenian frame, or that there is a conflict of arguably applicable rules or a gap.

In the Hart/Kelsen framework, shared by conceptual jurisprudence and policy analysis, there is no room for the activity that I would place at the center of a phenomenology of cores, frames, gaps and conflicts, a phenomenology that can account for determinacy and indeterminacy. This is the activity of legal »work « understood as the transformation of an initial apprehension (Husserl) of what the legal materials making up the system require, by an actor who is pursuing a goal or a vision of what they should require. (The conception of work here is inspired by Marx's Economic and Philosophical Manuscripts of I 844-45.)

Legal work, as I am using the term, whether aimed at cores or frames or at penumbras or conflicts or gaps, is undertaken »strategically. "The worker aims to transform an initial apprehension of what the system of norms requires, given the facts, so that a new apprehension of the system, as it applies to the case, will correspond to the extra-juristic preferences of the interpretive worker.

Legal work occurs after the initial apprehension of facts and norm, and after »unself-conscious rule application. «The interpreter »grasps « (a gestalt process, as in Kohler's Gestalt-Psychology) the situation as a whole as one in which a norm governs and the question is whether particular facts within the situation trigger its application so as to produce a sanction. Someone has died, and the court is asking, first, whether the defendant killed a person, and, second, whether the killing was a legal murder, and that »depends on the facts. "Often, once the facts are found, no one will even advert to the possibility of legal work directed at the interpretation of the norm that defines and punishes murder. The facts will be understood to establish guilt or innocence »of their own accord, « as the »norm applies itself « seemingly without any agency of the interpreter.

It is familiar that the facts come into legal being through the work of investigators, so that the facts presented depend on the work strategies and levels of effort of prosecutors and parties. It is also familiar that the advocates and the judge, and, at a more abstract level, the jurist, sometimes work to transform the initial apprehension of which norm governs and what it requires. This is »strategic behavior in interpretation. «

These are three types of strategic behavior in interpretation:

First, trying to find legal arguments that will produce the effect of legal determinacy for a rule different from the one that initially appeared self-evidently to govern the case, as for example by making it appear that there is necessarily an exception to the rule that covers the case, or that the case is covered by a different rule altogether.

Second, trying to make what looked like a self-evidently discretionary judicial decision (one in the penumbra or within the frame) appear to be one in which there is, after all and counter-intuitively, a particular rule whose application is required by the materials (i.e. the case falls within the core or all alternatives are outside the frame).

Third, trying to displace an initially self-evidently »valid « or legally required rule with a perception of the situation as one in which the judge is obliged to choose according to vague criteria between legally permissible alternative (i.e. 
moving an interpretation from the core to the penumbra or into a frame permitting judicial discretion).

In all these cases, the interpreter works to create or to undo determinacy, rather than simply registering or experiencing it as a given of the situation.

Work presupposes a medium, something that the worker »fashions."In this case, the medium is that body of legal materials which are considered relevant in establishing the meaning of the norm. This will certainly include the dictionary, with its definitions, and the legal dictionary with its quite different ones, and doctrinal commentary, and the full body of valid legal norms, perhaps legislative debates, perhaps case law. From our point of view, the question is not what count, officially, as »sources, « but what elements are sought out and deployed in fact in the work of advocacy or justification.

The worker works uses the legal materials to convince an audience of some kind (and himself as well) that an initial apprehension (his or that of another) of determinacy or indeterminacy was wrong. But there is nothing that guarantees that this enterprise will succeed. Work is neither cognition of binding law nor discretion in devising law according to »legislative preference. «It is between these two. The legal materials constrain legal work but the way a medium constrains any other worker. It constrains only against an effort to make the materials mean one thing or another.

To say that the interpretation of the rule was determinate is only to say that at the end of the work process the interpreter was unable to accomplish the strategically desired re-interpretation of the initially self-evident meaning of the norm. In other words, Critical Legal Studies (CLS), as I understand it, accepts fully the positivist idea that law is sometimes determinate and sometimes indeterminate. CLS rejects both the idea of global indeterminacy and the idea that there is always a correct interpretation, however obscure or difficult to arrive at. But it also rejects the idea that determinacy and indeterminacy are »qualities « or "attributes « inherent in the norm, independently of the work of the interpreter. Strategic success against initially self-evident determinacy (or self-evident indeterminacy) is a function of time, strategy, skill, and of the »intrinsic « or essential or »objective« or »real« attributes of the rule that one is trying to change. The »ontological « question is whether it is appropriate to regard the determinacy of the rule, meaning its insuperably binding or »valid « quality at the end of the period allowed for working on it, as its own attribute, something inherent to it. The alternative is that the determinate or indeterminate quality of the rule cannot be understood otherwise than as an »effect « - the »effect of necessity«produced contingently by the interaction of the interpreter's time, strategy and skill with an unknowable »being in itself « or »essential « nature of the rule.

The legal worker performs the classic phenomenological reduction or »bracketing « [epoché] (Husserl) of the question of whether the resistance of the rule to reinterpretation is a result of what it »really « is or merely an effect of time, strategy and skill. The worker proceeds by trying to change things, without a pre-commitment one way or another to an ontology of the norm. For the strategic interpreter nothing turns on deciding on the essence. The left phenomenological position within CLS adopts this attitude as well.

Stakes determine how much work to do. Max Weber's distinction between material and ideal stakes is useful here. The litigants may be materially motivated, and the judge too, but judges (and jurists) are obviously often conscious of only ideal stakes. They choose a work strategy because they understand their enterprise as having to do with »justice, « understood as non-identical with 
law application. They also understand the duty to achieve justice as »subordinate « to law. But this duty can be operative only after law is established. The conventional definition of the judicial (or juristic) role doesn't say anything about legal work, because the standard (positivist) model recognizes only cognition and discretion, and makes no place for work.

Those who understand interpretation as either cognitive or discretionary are likely to regard work designed to achieve a particular change in the self evident meaning of a norm, in a direction that is determined strategically, that is, extrajuristically, as illegitimate. I think the illegitimacy argument is incorrect.

First, most people agree that judges are supposed to work at interpretation, and have to decide how to orient their work. Indeed, most jurists would regard it as a violation of the duties of the judicial role for the judge simply to act on whatever meaning of the norm was initially self-evident, once it has been pointed out that there is another possibility. The reason for this is that the judge knows that work may change the initial appearance. He cannot take it as »true "merely because it is initially legally self-evident.

Faced with the obligation to work in one direction or another, judges (and jurists) often choose to orient their work to the goal of making their extrajuristic or legislative intuition of justice-in-rule-choice into the reality of judicial decision - these are the "activists, « in Unitedstatesean parlance. What Hart and Kelsen refer to as »legislative " motives we all understand to fall within the domain of »ideology. «An ideology is a »universalization project « asserting a conception of justice that is controversial, alleged by some to be mere rationalization of non-universal interests and by others to be universal - as well as leading to vindication of the interests alleged by its opponents to be merely partial (Mannheim, Habermas). Judges (and jurists) sometimes work not randomly in trying to make law correspond to justice but according to their commitment to well known universalization projects or ideologies. This posture is problematic because even if we readily acknowledge that judges are obliged by their role to work to make positive law correspond to justice, it is a premise of the liberal democratic theory of the separation of powers that ideology is not just »legislative " but that it is not for the judiciary (or for the jurist).

Judges often respond to the dilemma by claiming to work and attempting to work non-ideologically - bracketing their legislative preferences in deciding in which direction they will try to move frames or cores. But when they do this, they have to contend with the fact that their audience, and they themselves, understand different outcomes to respond, in many cases with high stakes, to different ideologies. Two very common judicial (and juristic) postures, in the presence of this dilemma, are »bipolarity « and »difference splitting. «In the first, the judge establishes, for himself and others, that he is an ideological »neutral « because he unpredictably alternates between the alternatives defined by conflicting ideologies. In the second, the judge establishes his neutrality by being a "centrist, « devising a solution that gives something to each side, but gives neither side all that it demands. These are bad faith solutions, in Sartre's sense in Being and Nothingness, because they avoid role conflict through denial (in Freud and Anna Freud's sense).

The position of the "activist « judge, who consciously or unconsciously pursues his own ideological commitments (rather than claiming neutrality because he is a wild card or a centrist) seems to me more ethically plausible. The judge knows that work may make the rule approach his legislative preference, but may not. Suppose he is committed to applying the rule if he cannot destabilize it by using 
accepted, conventional judicial techniques - that is by research into the legal materials that will lead to their reinterpretation according to accepted canons of legal reasoning.

Then why shouldn't he direct his work, time strategy and skill, to finding the argument that will make law correspond to his conception of justice? It seems plain, to me, that he would be acting illegitimately precisely if he failed to attempt this, in other words if he failed to make the attempt to rework positive law to make it correspond to his idea of justice. The judicial (and the juristic) role requires fidelity to »law « in the complex sense that combines a positive and an ideal element. This position, which legitimates juristic work intended to inflect the law in the judge's (or jurist's) preferred ideological direction, is, of course, »anarchist « (or at least »pluralist «) from the » Jacobin« point of view that locates legal legitimacy solely in the will of the people.

If we recognize that judges can and do work to change cores or frames (whether or not we regard this work as legitimate), then a basic Hart/Kelsen notion is undermined. This is what Kelsen calls the »dynamic conception, « in which the movement of norm creation is from the abstract to the particular or concrete. In Hart, it is the notion that adjudication »fills in « the penumbra, as well expressed by MacCormick in the following quotation:

»The thesis that even the best drawn laws or lines leave some penumbra of doubt, and this calls for an exercise of a partly political discretion to settle the doubt, is not particularly new, it is but the common currency of modern legal positivism. (...)

A crucial point, though, is that one ought not to miss or under-estimate the significance of line-drawing or determination as already discussed. The law really does and really can settle issues of priority between principles by fixing rules, and even when problems of interpreting rules arise, these focus on more narrowly defined points of interpreting rules than if the matter were still at large as one of pure principle. Fixing rules can be done either by legislation or by precedent; most commonly, in a modern system, by the two in combination. It is one of the gifts of law to civilization that it can subject practical questions to more narrowly focussed forms of argument than those which are available to unrestricted practical reason. $\ll^{2}$

If strategically directed work in interpretation can destabilize initial apprehensions of cores or frames, then this statement is much too optimistic about the "gifts of law to civilization. "In my extended treatment of this topic, I suggest that »small « questions can have very large ideological stakes. 3 Second, I suggest that contrary to MacCormick's suggestion, the same arguments of principle recur at each level of abstraction, so that settling issues "further down « in the pyramid will involve arguments no less controversial than those that apply at the top.

But for my purposes here, there is a quite different point: even after an interpretation is settled, work can destabilize it. This means that work can »inflect « or »shift « cores and frames. There is now a »from the bottom up « dynamic that counteracts to one extent or another Hart's and Kelsen's top down, abstract to concrete, dynamic. Rather than MacCormick's progressively narrower focus for issues of controversy, the worker can hope to split open cores or dissolve them.

\footnotetext{
2 N. MacCormick, »Reconstruction after Deconstruction: A Response to CLS, « Io Oxford Journal of Legal Studies 539, 553-554 (1990).

3 Duncan Kennedy, Critique of Adjudication.
} 
So work does more than fill the frame or the penumbra dynamically with strategically determined norm choices. Ideology inflects work which inflects frames and cores, which in turn provide, in the coherence view, means to further destabilizations of other cores and frames. In this view, the body of valid law, that is law that is regarded by legal workers in their initial encounter with the materials as core or frames, is best understood, first, as an historical work product of lawyers, jurists and judges pursuing conflicting ideological projects (which may be centrist, in the above sense), and, second, as always but unpredictably subject to destabilization by future ideologically oriented work strategies.

\section{Misreadings of the CLS Indeterminacy Critique}

In order to understand how the above position, representing one, possibly the dominant position within critical legal studies since about I 985 , and, today, 4 the only remaining explicitly argued CLS position, it may be useful to contrast it with a typical misreading of CLS from within the mainstream of Anglo-American legal philosophy, in this case by my friend Brian Bix:

»... [I]n particular, CLS theorists argued for the radical indeterminacy of law: the argument that legal materials do not determine the outcome of particular cases. CLS theorists generally accepted that the outcomes of most cases were predictable; but this was, they claimed, not because of the determinacy of the law, but rather because judges had known or predictable biases. The legal materials, on their own, were said to be indeterminate, because language was indeterminate, or because legal rules tended to include contradictory principles which allowed judges to justify whatever result they chose.5 The CLS critiques have generally been held to be overstated; ${ }^{6}$ though there may well be cases for which the legal materials do not give a clear result, or at least not a result on which everyone could immediately agree, this negates neither the easiness of the vast majority of possible disputes nor the possibility of right answers even for the harder cases. «7

I. The left-phenomenological CLS tendency (arguably the dominant tendency) argued that the legal materials do or do not determine the outcomes of cases only in interaction with the argumentative strategies of jurists pursing objectives with limited time and resources. The materials are one part of the determination, but only in combination with interpretive activity which is not cognitive but rather consciously or unconsciously strategic. It is not and never was the position of this tendency within CLS that the legal materials »do not determine the outcome of particular cases « but rather that their influence is mediated and that their »intrinsic« or »essential« determinacy or indeterminacy is unknowable.

The legal materials are »indeterminate only in the sense that sometimes it is possible to destabilize initial apprehensions through legal work - »intrinsically « or »essentially « they are neither determinate nor indeterminate. True, we often initially apprehend them as determining the outcome of a particular case or, on the

\footnotetext{
4 Zur Rechtskritik der Critical Legal Studies und ihrer Entwicklung: G. Frankenberg, Der Ernst im Recht, KJ 3/1987, 28 Iff. und ders., Critical Legal Studies etc., in: A. Fischer-Lescano/S. Buckel (Hrsg.),Rechtstheorie 2006.

5 Mark Kelman, A Guide to Critical Legal Studies, 1987.

6 Larry Solum, 1987.

7 Brian Bix, in: The Oxford Handbook of Legal Studies, hrsg. v. Peter Cane and Mark Tushnet, 983.
} 
contrary, as not determining the outcome (because the case falls in the penumbra or within the frame, for a Hart/Kelsen person, or within the areas of indeterminacy of conceptual analysis or policy analysis for advocates of those methods). On this basis, we can predict results when we anticipate that no work will be done to destabilize the initial apprebension. And it will often be possible to predict that no such work will be done because the extant ideological projects empowered through the judiciary are in agreement with the initial apprehension - in other words because actors with radical or outlying ideological projects do not work as judges or as influential jurists.

In a second moment, the legal materials are determinate in those cases where after legal work to the point of exhausting the time and resources available, the interpreter finds himself or herself unable to destabilize the initial apprehension that there is an applicable norm and that that norm decides the case for one party or another. On this basis, we can predict results when we anticipate that the work done to destabilize outcomes will fail. In this case, we are making a prediction about the outcome of the interaction between interpretive work and the unknowable »essence« of the materials. Again, the centrist ideologies shared by judges and jurists in capitalist countries are an important factor in this kind of prediction.

CLS writers have worked from the beginning and continually, to figure out how rules that seemed likely to resist even the most sustained effort at transformation through interpretation, given the moderate left or moderate right ideological preferences shared by virtually all judges in all capitalist countries, have massive and unjust impacts on oppressed groups. This is the CLS contribution to the sociology of law and left wing law and economics.

2. The notion that the indeterminacy of language explained the way in which law is indeterminate has had some influence in CLS, particularly on the early work of Unger, and on writers like Boyle, who purported to speak for CLS as a whole. From the beginning, a more influential current argued that rules vary in »formal realizability, « or »administrability, « so that the simple linguistic critique is often trivial, as are all other arguments for »global « indeterminacy.

Bix's attribution to CLS of a notion that »legal rules [tend] to contain conflicting principles « is puzzling. The CLS claim was, à la Dworkin, ${ }^{8}$ that principles, policies and rights, and indeed world views, are all part of the commonly deployed sources of law, but, contra Dworkin, that they are in ineradicable conflict, within each of us as well as between us. Their conflictual presence is reflected in the more concrete "valid legal norms of the system, "which CLS, following legal realism, understands to be, always, complex compromises of those conflicts. Because the rules are compromises, rather than a coherent working out of one or another over-arching principle, they are much more open to destabilizations of various kinds than coherentist writers acknowledge.

3. The »biases « of judges are relevant because they orient legal work by judges (and other jurists) to transform initial apprehensions of what the materials require in the particular direction suggested by the judges material or ideal interests (loosely, the judge's or jurist's ideology). Whether the jurist will succeed in the work of making the materials conform to his ideological or material extra-juristic strategic motive is never knowable in advance (though as with any uncertain future event, we can make odds). Jurists constantly accept 
interpretations according to which the positive law is contrary to their view as to what it ought to be.

Moreover, »biases « or ideology do not determine jurists' work strategies in any way more determinate than the system of legal norms determine outcomes. Ideologies are indeterminate in just the way that the legal order is. There is an hermeneutic circle at work here, in which the indeterminacies of each level get resolved by appeal to a deeper level with its own indeterminacies, and so on, back to the starting point, in which legal ideas influence ideology as well as vice versa.

4. The CLS critiques have been held to be overstated (or to indicate mental incompetence or insanity) within a mainstream that has misunderstood them more or less in the manner of Brian Bix in the above passage, although they are quite often misinterpreted, not as above, but as claiming »determination in the final instance by the base, or as a vulgar Marxist claim that the judges are the »executive committee of the ruling class, « and proceed case by case to further »the interests of capital. «The misreadings derive in part from the more or less complete ignorance both of phenomenology and of critical social theory among mainstream Unitedstatesean legal theorists, in part from the limited resources that mainstream legal philosophers devote to marginal currents (Bix is exceptional in his familiarity with CLS writing), and in part to the normal investment of mainstreams in reproducing the marginality of the margins.

5. Everyone knows that »there are cases for which the legal materials do not give a clear result. « And that there are cases in which the legal materials do not give a result »on which everyone could immediately agree. «The CLS claim is that the question of what proportion of actual or imaginable cases have determinate outcomes, given the legal materials, has to be asked taking into account the possibility that legal work will destabilize the initial apprehension of what the materials require. Once we take into account that determinacy is a function not just of the words of valid norms and the content of other sources, but of an interaction - between the resources and strategies of whoever has the power to do legal interpretation, and the »thingness « of the materials - statements about the »vast majority of disputes « are simply meaningless.

6. That results are not determinate in some cases, according to Bix, does not »negate the ... possibility of right answers even for the harder cases. « The only intelligible meaning of a »right answer « in a case, hard or easy, given the phenomenology above, is that having worked with the time and resources available and according to a chosen strategy, the interpreter can't find an alternative to some particular apprehension of what rule applies and what it requires when applied. In other words, after performing the phenomenological reduction, the »right answer « is the one that is produced by an argument having the »effect of necessity." As to whether there is a right answer in the sense of one available to cognition, CLS takes the position of Kant as to the »thing in itself.« 